\title{
THE IMPACT OF HORIZONTAL STRATEGIC ALLIANCES ON THE U.S. STEEL INDUSTRY
}

\author{
Lucy Ojode \\ Texas Southern University \\ Houston, TX
}

\begin{abstract}
Despite the popularity of strategic alliances among firms, the public is ambivalent about the industry impact of horizontal alliances. It is not apparent that the benefits of alliances to the firm also accrue to the industry. This paper examined the U.S. steel industry data from 1977 to 1997 to determine the potential impacts of capability horizontal alliances on industry competitive structure. The results are indicative of positive impacts on industry competitiveness (profitability and productivity) and competitive structure (price competition and declining industry concentration). A capability hypothesis is offered that posit that horizontal alliances that enhance partner firms' 'capabilities may diffuse critical capabilities or 'best practices' within an industry thereby raising the average level of competitiveness in the industry and inducing competitive pressures that can result in price competition and erode industry concentration.
\end{abstract}

Strategic alliances are the "relatively enduring inter-firm cooperative arrangements that involve flows and linkages that utilize resources and/or governance structures from autonomous organizations, for the joint accomplishment of individual goals linked to the corporate mission of each sponsoring firm" (Parkhe, 1991: 581). Investors generally view alliance announcements favorably (Das, Sen, and Sengupta, 1998) since alliances enable firms to share resources, manage risk, and create value (Chan et al., 1997). However, consumers are wary of horizontal alliances or cooperative arrangements between competing firms that could result in anti-competitive maneuvers as partner firms seek to manage industry-induced uncertainties (Burgers, Hill, and Kim, 1993). Yet, horizontal alliances also provide proximity to competitor capabilities and expose these capabilities as 'templates' that partners could use in 'learning-by-doing' in developing new capabilities while leveraging current stock of capabilities (Hamel, 1991). Therefore, horizontal alliances that enhance capabilities such as process technologies (Mueller and Herstatt, 2000) could diffuse best practices or innovation and induce competitive rivalry within an industry. While economic literature is elaborate on the anti-competitive consequences of horizontal alliances, competitive consequences have been confined to scale economies (e.g., Williamson, 1968). The potential to diffuse capabilities and induce industry competition is relatively unexplored, a lack this paper addresses by examining 
the potential impact of horizontal alliances on industry competitive (pricing and concentration) structure.

\section{Horizontal Alliances and Organizational Capabilities}

Capabilities are routines or repeated complex organizational patterns of resource and activity coordination that enables efficient functioning (Nelson and Winters, 1982). Capabilities are embedded in organizational factors such as physical characteristics of production capacity that symbolize the potential economies of scale and scope determined by throughput. "Such economies depend on knowledge, skill, experience, and teamwork-on the organized human capabilities essential to exploit the potential of technological processes" (Chandler, 1990:24). Firms focus on capabilities embedded in intangible or information resources such as, technology, consumer trust, brand image, control of distribution, corporate culture and management skills that have a significant potential for sustaining competitive advantage (Barney, 1991). However, such intangible resource based or 'strategic' capabilities are costly to assemble and maintain (Chi, 1994; Teece and Pisano, 1994). Firms generally lack ancillary capabilities necessary for all activities in the production chain mandating outsourcing of some capabilities. Although such capability outsourcing can be consummated in arms-length market transactions, collaborative modes or hybrid organizational forms such as horizontal strategic alliances often economize on transaction costs (Chi, 1994; Dyer, 1997). Alliances entail interdependence that reduces the risk of opportunism and repeated access to a partner's array of capabilities enhances transferability of tacit knowledge and complex non-codified routines and information-based capabilities (Kotabe and Swan, 1995).

Horizontal alliances thus provide access to desired capabilities and reduce partner costs for assembling new or enhancing existing capabilities while providing opportunities for firms to influence competitive environment (Kogut, 1988). As partners absorb competitor routines, critical industry capabilities (e.g., best practices) may diffuse across partners within an industry. Consequently, extensive horizontal alliancing that result in enhanced individual partner capabilities such as improved cost structures and average competitiveness can diffuse critical capabilities and induce industry rivalry. This pro-competition capability horizontal alliance conjecture is contrary to the 'winner-take-all' zero-sum game competitive disposition of rent seeking firms, but is consistent with rent-seeker's quest for synched competitive and cooperative advantages (Lado, Boyd, and Hanlon, 1997).

\section{Literature Review and Hypotheses Development}

\section{Resource-based and Competitive Models}

A growing resource-based and capabilities literature (e.g., Mahoney and Pandian, 1992; Penrose, 1959; Teece, Pisano, and Shuen, 1990; Wernerfelt, 1984) focuses on firm resources to explain sustainable competitive advantage (Barney, 
1991). However, the resource-based perspective is silent on competitive dynamics (Schoemaker, 1993). Competitive models on the other hand, 'match' firm resources to environmental (industry) opportunities or conjure up defensive reactions to environmental threats. Such models match independent internal (firm resources and capabilities) and external (industry) analyses as if managers perform these tasks independently. Yet, in practice decision makers often adopt strategies that address firm resources and competitive positioning simultaneously. Such strategies include horizontal alliances that can enable partners to internalize competitor capabilities to provide quality products efficiently and /or reduce risks hence cost of capital while monitoring competitor moves simultaneously.

\section{Horizontal Alliances as Competitive Tools}

Understanding capability-based horizontal alliances as a competitive tool resides in the assumption that firm capabilities determine competitiveness. That is, the creation and maintenance of an economic rent stream depend upon inimitable, idiosyncratic, rare and non-substitutable resources or capabilities (Barney, 1991). Competitiveness then entails maintaining superior capabilities that are costly to imitate and less substitutable, but such capabilities are costly to develop and maintain, hence the resort to horizontal alliances to hasten capabilities development or through which to borrow in cases of capability gaps (Leonard-Barton, 1995). However, horizontal alliances expose capabilities that underlie a firm's competitiveness to learning race competitors and even when an alliance enhances capabilities for all partners, some partners may still consider the relationship disadvantaging due to high inter-partner competition (Hamel, 1991). Consequently, alliance value may also depend on gains that firms perceive as accruing from the relationship vis-à-vis their partner's gain and the level of trust in the partners (Hamel, 1991; Jennings et al., 2000). Thus, capability-based horizontal alliances must enhance partner capabilities and add value beyond perceived partner costs to sustain mutual support (Mariotti, 1996). Despite such delicate within-alliance negotiations, horizontal alliances can precipitate efficient resource utilization as firms outsource non-core resources from partners while focusing on core capabilities. For instance, partners can share production facilities to increase utilization and create efficiencies that promote industry productivity.

Alliances also enable firms to share cost of developing technical knowledge that can increase the level of resources dedicated to knowledge acquisition, thereby enhancing chances of successful innovation (Goes and Park, 1997; Kotabe and Swan, 1995). For example, firms that are endowed with capital but that lack technological prowess may partner with less resourced but technologically agile competitors to overcome mobility barriers into certain industry segments. For instance, the U.S. Steel-Nucor Direct Reduced Iron (DRI) project provided opportunity for the capital-endowed but technologically inept integrated steel producer to spearhead the development of the DRI technology in conjunction with the relatively capital poor but technologically agile minimill. The joint effort boosted U.S. Steel's modernization efforts and Nucor's integrated steel produc- 
tion capabilities. Similarly, alliances can promote industry competitiveness by spreading best practices and triggering competitive benchmarking as partner firms learn, absorb, and leverage more successful routines and procedures resulting in innovative products, improved revenue generation and/or efficiency. For instance, the Nucor-Yamato Kogyo alliance enabled Nucor to increase labor productivity to one person-hour a ton in 1991, about three times the integrated producers average productivity (Iron Age, May 1991). Two years later, Birmingham Steel benchmarked Nucor's feat and raised its labor productivity to 1.4 person-hours a ton (Iron Age, Aug. 1993). The ensuing minimill rivalry triggered revolutionary cost cutting and quality enhancement programs among the integrated producers thereby raising industry productivity.

\section{Uncertainty Management Horizontal Alliances}

Firms may adopt horizontal alliances to manage uncertain environments. Research advances that alliances hold potential as flexibility mechanisms for investing in the option to expand in risky markets (Kogut, 1991) and as a risk buffer (Burgers, Hill and Kim, 1993). As flexibility mechanisms, alliances enable partner firms to expand or to divest at minimal cost (Hurry, 1993) and as a risk buffer, alliances spread risk between partners and reduce partners' cost of capital or discounting rate. Therefore, lower cost results whether partner firms adopt alliances for strategic flexibility or risk buffer.

\section{Horizontal Alliances and Foreign Competition}

Horizontal alliances tend to increase industry capacity by lowering mobility and entry barriers. For instance, otherwise marginal firms that possess limited critical capabilities may capitalize on these capabilities by partnering with competitors that have enabling complementary resources such as financial capital. Foreign competitors in particular may partner with domestic firms in order to evade tariffs and lower entry costs (Hurry, 1993). While such resource pooling alliances may enhance partners' competitiveness (Mueller and Herstatt, 2000), they may also raise industry capacity and induce rivalry that could impact industry profitability negatively. In summary, the discussion on horizontal alliances indicates that the strategy enables partners to absorb and leverage routines and procedures that result in improved revenue generation and/or efficiency. Alliances also increase resources dedicated to innovation pursuit and enable efficient risk management. However, potential increase in industry capacity may moderate these productivity and efficiency gains at the industry level.

Hypothesis 1: Horizontal alliance intensity will be positively related to industry performance.

\section{Horizontal Alliances: Capability Diffusing or Market Power Driven?}

Despite the recognition that a balance between conflict and cooperation is an integral part of competitive dynamics (Schelling, 1980), competitive models 
tended to preclude co-operation (e.g., Porter 1980). As a result, horizontal alliances were regarded as compromising industry competition (Stuckey, 1983), hence, the market-power hypothesis that viewed the strategy as manipulative anti-competitive maneuvers that benefited producers at consumer expense. Such maneuvers are attended by industry consolidation and a general appreciation in prices for commodity or homogenous product markets (Bhaskar, Manning, and To, 2002). Thus, market power driven horizontal alliances could be linked to a general appreciation in product prices and increasing market concentration (Stuckey, 1983). However, if horizontal alliances provide efficiencies, make partner firms more competitive, and diffuse desirable capabilities within an industry, then the behavior could raise the average level of competitiveness that could induce rivalry in the industry. As partner firms' preferences for successful routines and procedures coalesce to diffuse 'best practices,' the efficiency gains and diffused capabilities can increase mobility and rivalry that can induce competitive pressures conducive to price competition (Goolsbee and Chevalier, 2002). The likelihood of price competition increases for capital-intensive excess capacity mature industries (Grant, 1991). Therefore, capability driven horizontal alliances are likely to be associated with a general decline in product prices.

\section{Hypothesis 2: Horizontal alliance intensity is inversely related to product pricing within an industry.}

If market power driven, then horizontal alliance partners would increase market share at the expense of non-alliance competitors (Berg and Friedman, 1981). However, if capability and efficiency driven, then horizontal alliances will enhance partner firms' capabilities and improve market position in the long run (since capability development takes time) but not in the short run (Berg and Friedman, 1981). Also, widespread capability horizontal alliances that enhance individual partners' competitiveness can diffuse capabilities (best practices) among industry incumbents and boost capabilities for effective presence in industry segments thereby enhancing mobility and diluting market concentration. Similarly, horizontal alliances can lower mobility and entry barriers to otherwise marginal and even foreign firms thereby preventing market domination. Lower entry barriers could potentially increase capacity and dilute dominant incumbents' market shares thereby dampening industry concentration. Industry capacity could also arise from new establishments. For instance, competing alliance partners that establish joint ventures usually establish new facilities (Hamel, 1991). Therefore, widespread horizontal alliances can diffuse capabilities thereby induce mobility, rivalry, market entry and increase capacity that can dilute industry concentration.

Hypothesis 3: Horizontal alliance intensity is inversely related to industry concentration. 


\section{Methods}

\section{Data}

The industry impact of horizontal alliances was estimated through least-squares multiple regression models of the U. S. steel industry's longitudinal data from 1977 to 1997 . This period is ideal for an investigation of the steel industry since it traverses monumental changes from the 1970's decade of crises, the 1980's decade of catastrophe, and the 1990's renaissance (Stubbles, 1995). The 1997 demarcation is appropriate since a major source of industry data, the U.S. Census Bureau, changed data classification systems from the Standard Industrial Classification (SIC) to the North American Industry Classification (NAIC) in 1997. These changes make pre and post- 1997 industry data incomparable. Two sets of models were developed to evaluate the impact of horizontal alliances. The first set represents the impact of horizontal alliances on industry economic performance or profitability and efficiency while the second represents the impact on industry structure or industry concentration and product pricing within various segments of the U.S. steel industry.

\section{Capability Horizontal Alliances}

Measuring capability horizontal alliances posed a challenge because of the difficulty of estimating organizationally embedded and complex intangible resources such as capabilities (Godfrey and Hill, 1995). Therefore, we used horizontal equity joint ventures to estimate capability alliances (e.g., Berg and Friedman, 1977). Horizontal joint ventures provide access to competitor capabilities and may signify partners' motives to leverage and/or develop idiosyncratic resources (Chi, 1994; Hamel, 1991). In particular, the level of a partner's equity involvement in a joint venture may signify desire for control that may symbolize the strategic significance of the underlying resources (Ojode, 2000). Partner firms could target competitors' critical capabilities to enhance their own. Thus to counter such 'learning race' motives or to reduce their impacts, joint venture partners maintain concurrent in-house capability development efforts (Hamel, 1991). Consequently, firms that invest in capability horizontal alliances also tend to support in-house developed capabilities. Berg and Friedman (1977) used this linkage between in-house development efforts and joint venture activities to substitute joint venture intensity for R\&D expenditures, arguing that: "Joint ventures represent a potential source of supply for the required technical inputs which reduces the time-lag and risks from the levels associated with exclusively in-house R\&D activities... [thus] joint ventures can be viewed as substitutes for expenditures on in-house $R \& D$ and pilot production facilities...so that highly innovative industries would be seen to engage in both more internal R\&D and more joint ventures, although these two remain substitutes."

The U.S. steel industry's equity joint venture data was collected from various issues of the American Metal Market Publication, Metal Bulletin, Steel Alert, New York Times, Wall Street Journal, U.S. ITC steel industry reports, the Business Wire, and Iron Age publications. To avoid counting non-operative alliances, 
only joint ventures that were corroborated through company records to have been operating for more than a year were included in the study. Figure 1 below provides an overview that indicates increasing incidence of horizontal equity joint ventures in the U.S. steel industry during the 1977-1997 period. Other industry data came from Census of Manufacturers Surveys. Previous industry studies such as, Acs (1984), Barnett and Crandall (1986), Berg and Friedman (1978), and Hogan (1994) also provided a rich source of qualitative data on the U. S. steel industry's structural characteristics from 1960s to 1990s.

\section{Figure 1}

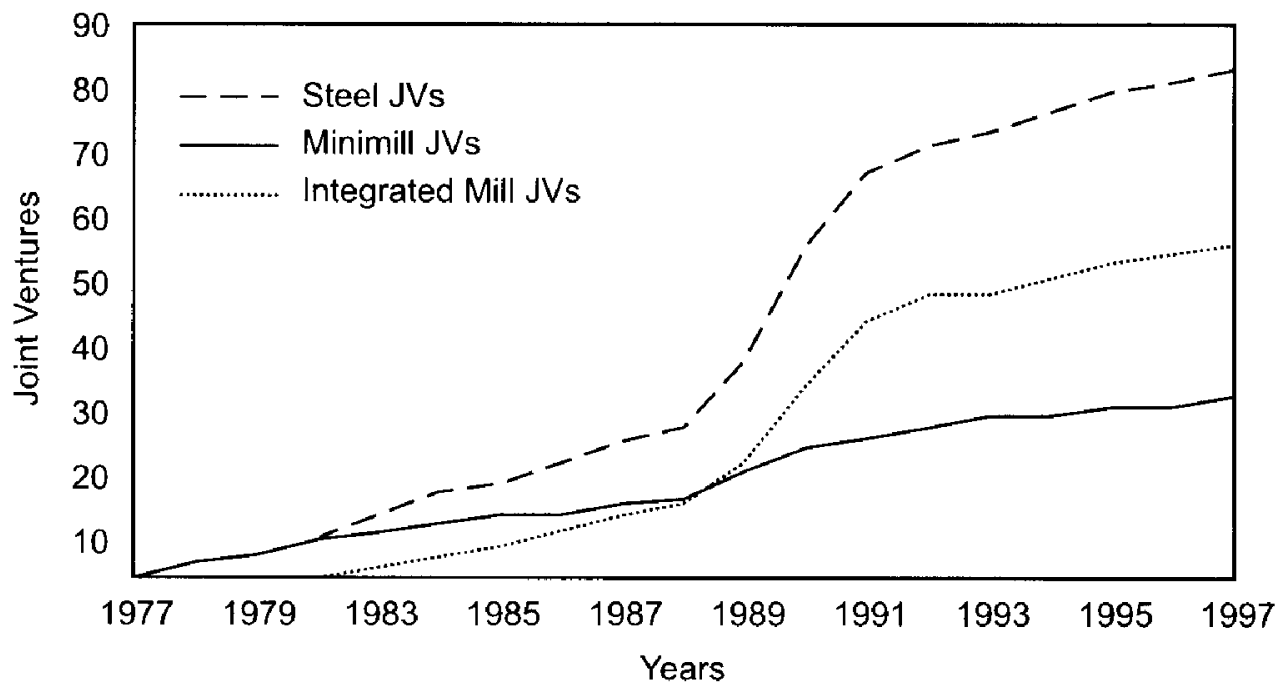

\section{Industry Performance}

The four-digit SIC classification 3312 was adopted to define the U.S. iron and steel industry. This classification covers Steel Works and Blast furnaces, including Coke Ovens and Rolling Mills. It is representative of the iron and steel industry since firms in this category produce more than $90 \%$ of three-digit SIC classifications 331 and 332 products. Industry economic performance and status data were obtained from Standard \& Poor's Industry Surveys. These surveys provide periodical industry reports including income statement and balance sheet as well as industry financial ratios from information gathered through trade associations such as the American Iron \& Steel Institute (AISI).

\section{Industry Structure}

The impact of horizontal alliances on the competitive structure of the U.S. steel industry was estimated through steel product prices and industry concentration trends from 1977-1997. Price data were drawn from the 3-digit SIC classifications 331 and 332 composed of the 4-digit SIC 3312 (defined above), 3313-Electro-metallurgical products, 3315-Steel wire and related products, 3316-Cold finishing and steel shapes, 3317-Steel pipe and tubes, 3321-Gray 
iron foundries, 3322-malleable iron foundries, and 3325-Steel foundries. Out of these classifications nine most common steel products (Beams or Structural Steel, Steel Plates, Hot-Rolled Sheet, Cold-Rolled Sheet, Galvanized, Stainless, Coldfinished, Reinforcing Bar, and Wire Rod) were identified. These nine products had mill-based prices listed in various issues of the Iron Age and the Purchasing publications from 1977-1997. List prices are more appropriate than transaction prices because they only incorporate the underlying industry factors to offer a better estimate of price behavior in the U.S. steel market (Acs, 1984). Industry concentration data were drawn from Census of Manufacturers statistical abstract estimates and from Standard \& Poor's Industry Surveys.

\section{Analysis}

\section{Performance}

It was argued in the first hypothesis that horizontal alliances could result in enhanced competitiveness of partner firms from acquired capabilities and from efficiencies due to costs, information, and risk sharing. If alliances enhance capabilities, provide efficiencies (through shared resources and increased capacity utilization), and increase partner firms' competitiveness, then pervasive horizontal alliancing could have a positive impact on the economic performance of an industry. However, if horizontal alliances increase industry capacity rather than capacity utilization (efficiency) then the positive impact on performance may be lower. Therefore, the alliance-performance relationship is modeled as follows:

\section{INDUSTRY PERFORMANCE $=\alpha+\left[\beta_{1}\right.$ INDUSTRY PERFORMANCE $+\beta_{2}$ JOINT VENTURE INTENSITY \\ $+\beta_{3}$ NEW CAPITAL EXPENDITURE/SALES \\ $+\beta_{4}$ INDUSTRY ACQUISITIONS $]_{t-n}+\varepsilon$}

where subsequent industry performance is a function of current performance and capability horizontal alliances within an industry. However, since capabilities may also be developed through in-house R\&D or new capital expenditures or through mergers and acquisitions, we control for these alternative resource mobilization strategies. Economic performance in the model is represented by profitability--measured as Return on Assets (ROA) and productivity --measured as Manufacturing Value Added per Production Worker Hour (MVA/PWH). Return on Sales (ROS), Return on Equity (ROE) and operating margin performance measures were used for model robustness.

Table 1 following provides summary statistics indicating that profitability averaged $-0.58 \%$ (ROA), $-0.21 \%(\mathrm{ROS})$, and $-2.46 \%$ (ROE) while manufacturing value added averaged $\$ 45.83$ per production worker hour, and operating margin averaged $9.83 \%$ in the industry during the $1977-1997$ period. The industry averaged 0.94 joint ventures per firm a year (alliance intensity), $3.60 \%$ of sales invested in new capital equipment, 7.43 horizontal acquisitions, 100 million 


\section{Table 1}

\section{Summary statistics and correlation matrix for performance model Dependent variable: Steel industry profitability and productivity $(\mathbf{N}=\mathbf{2 0})$}

The first number represents the estimated correlation and the second number represents the p-value under the hypothesis of zero correlation.

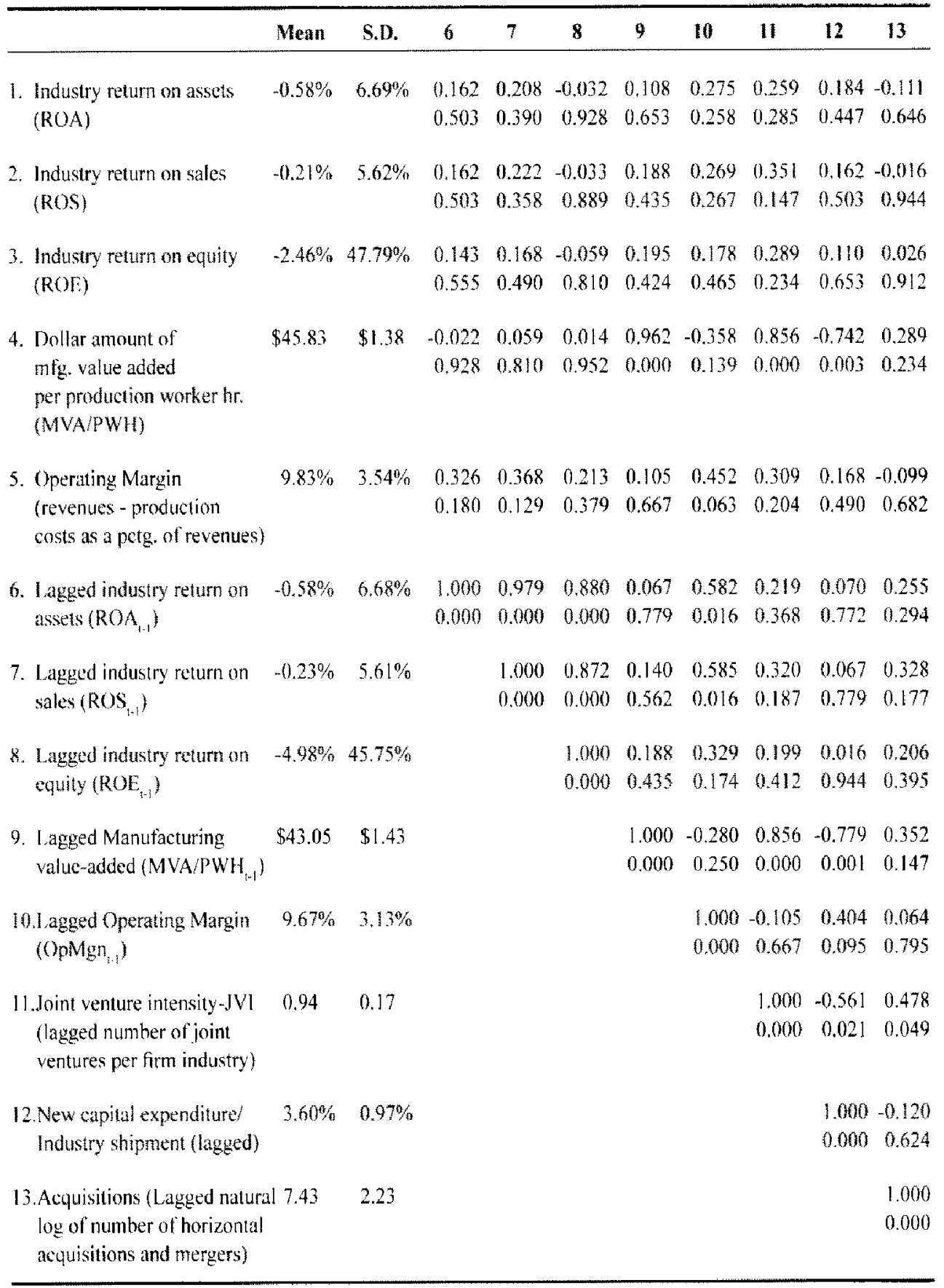


tons in domestic shipment and capacity utilization $(76.71 \%)$ per year between 1977 and 1997. Table 1 also indicates high positive correlation between alliance intensity and productivity (MVA/PWH) and acquisitions although industry profitability and alliance intensity are uncorrelated while alliance intensity and capital expenditure are negatively correlated. Despite potential for multicollinearity in the model, no remedy was necessary since potential impact on the theoretically important alliance variable did not reduce t-statistics for its coefficient below the critical level of 2 that requires correction (Kennedy, 1992).

\section{Impact on Industry Competitive Structure: Price Model}

It is argued in Hypothesis 2 that capability horizontal alliances that enhance individual partner capabilities could diffuse critical capabilities (best practices) within an industry thereby inducing rivalry and potential for price competition or a general declining trend in product prices. The following is a model that estimates price of steel as a function of industry joint venture intensity (JVI) controlling for input costs, capacity utilization, and demand as follows:

LnPrice $_{i t}=\beta_{0}+\beta_{1}\left[\mathrm{JVI}_{1-1}\right]+\beta_{2}$ LnCost $_{\mathrm{it}}+\beta_{3} \mathrm{CUtil}_{1}+\beta_{4} \mathrm{LnDmnd}_{1}+\beta_{5}$ LnIMPT $_{t}+$ $\beta_{6} \operatorname{LnSUBS}_{\text {it }}+\varepsilon_{\text {t }}$

where Price $_{i t}$ is the average annual list price (adjusted for inflation) of steel product $i$ at time $t$. Industry alliance intensity, JVI, is the average number of horizontal joint ventures per firm in the industry at time $t$. Reflective of variation in industry competitive structure, the trend of steel prices is inversely related to alliance intensity in the industry. Costs (direct production labor and raw material requirements) constitute the largest components of a manufacturing product and form the base price criterion (Acs, 1984). The variable cost of producing product $i$ at time $t$, LnCost $_{\mathrm{il}}$ is therefore expected to relate positively to the trend of product pricing. This variable is measured as the sum of natural logarithm of the list price of scrap and the average cost of electricity whenever $i$ is a minimill product, but the sum of natural logarithm of real price of iron ore and the average cost of fuel whenever $i$ is an integrated mill product. The minimill and integrated costs are averaged whenever $i$ is a specialty product. Industry capacity utilization represents potential supply since the price mark-up over costs is a function of the pressure of demand on capacity. A higher capacity utilization reduces production costs and could boost supply and induce price reduction.

The LnDmnd, (natural logarithm of the value of steel shipments plus net imports at time t) represents demand that is endogenous in the model above since price is a function of both demand and supply. Supply on the other hand is a function of imports, costs, and other industry factors as described above. Following is a simultaneous equation that reflects this endogeneity:

$Q_{d}=f($ Price, Imports, Substitute Price)

$\mathrm{Q}_{\mathrm{s}}=\mathrm{f}($ Price, Industry Joint Venture Intensity, Capacity Utilization, Costs) 
The identified simultaneous equation is solved through a two-stage least-squares technique, a special case of instrumental technique that uses the best instrumental variables (Kennedy, 1992). Thus, in the equations above, demand is instrumented with imports, substitute price, and price. The estimated demand is then used with other exogenous variables to estimate price. A good instrumental variable is highly correlated with the regressor for which it is acting as an instrument (Kennedy, 1992). Therefore, demand is considered a good instrumental variable in the model above since it is highly correlated with the price and import variables. LnIMPT, (natural logarithm of the value of steel imports at time t) represents imports and LnSUBS (natural logarithm of the list price of the corresponding aluminum product at time $t$ ) represents price of substitute products. Table 2 following provides summary statistics for the model.

Table 2 shows average real producer price ( 1987 dollar) per short ton ranging from $\$ 335.54$ for reinforcing steel bar (rebar) to $\$ 1,736.20$ for stainless steel during 1977-1997 period. The table also shows that prices of integrated mill products (numbers 1-5 \& 7) were less volatile than those of the minimill products (reinforcing bars or rebar and wire rods) while stainless steel (a steel processor's product) price volatility was higher than for all integrated products save for Hot-Rolled Sheet, but lower than minimill products price volatility. Of integrated products, Cold-Rolled Sheet and Cold-Finished Steel (numbers $4 \& 7$ ) prices were least volatile. These products represented the least contested steel market segment during the 1990s (Iron Age, August 1993).

Table 2 also indicates positive correlation between alliance intensity and capacity utilization, alliance intensity and production costs, production costs and substitute prices, capacity utilization and demand, and between imports and demand. However, the import and substitute variables are incorporated in the models indirectly to instrument the demand variable. Therefore, potential multicollinearity resulting from the correlation between demand and capacity variables are reduced since the actual demand used in model estimation is instrumented. Potential 'leftover' multicollinearity resulting from correlation between the other independent variables is addressed by estimating a set of three models (a full model and two reduced models) for each of the nine products and by the 2SLS technique's robustness and tolerance to high correlation (Kennedy, 1992).

\section{Industry Concentration}

Concentration trends provide indications about the competitive structure of an industry (Scherer, 1980). For instance, high concentration characterizes mature or traditional industrial markets where competition entails price and market share battles (Grant, 1991). Hypothesis 3 argues that capability horizontal alliances can induce industry mobility, rivalry, and market entry that can increase capacity thereby dilute industry concentration. Thus, we can model industry concentration as a function of horizontal alliances, capacity, and production costs:

Concentration $_{t}=f($ Horizontal Alliance Intensity, Capacity, Costs), 
Table 2

\section{Statistics and correlation matrix for steel prices model $(\mathbf{N}=\mathbf{2 0})$}

The first number represents estimated correlation, the second p-value under the hypothesis of zero correlation.

\begin{tabular}{|c|c|c|c|c|c|c|c|c|c|c|}
\hline & Mean* & S.D. & 10 & 11 & 12 & 13 & 14 & 15 & 16 & 17 \\
\hline 1. Beams or Structural Steel & $\$ 381.86$ & $\$ 101.25$ & $\begin{array}{r}-0.493 \\
0.042\end{array}$ & $\begin{array}{r}-0.822 \\
0.001\end{array}$ & $\begin{array}{l}0.019 \\
0.936\end{array}$ & $\begin{array}{l}0.103 \\
0.674\end{array}$ & $\begin{array}{l}0.280 \\
0.250\end{array}$ & $\begin{array}{r}-0.366 \\
0.131\end{array}$ & $\begin{array}{r}-0.871 \\
0.000\end{array}$ & $\begin{array}{l}0.438 \\
0.070\end{array}$ \\
\hline 2. Steel Plates & $\$ 394.10$ & $\$ 98.76$ & $\begin{array}{r}-0.398 \\
0.101\end{array}$ & $\begin{array}{r}-0.743 \\
0.000 \\
3\end{array}$ & $\begin{array}{l}0.100 \\
0.682\end{array}$ & $\begin{array}{l}0.079 \\
0.741\end{array}$ & $\begin{array}{l}0.305 \\
0.208\end{array}$ & $\begin{array}{r}-0.159 \\
0.509\end{array}$ & $\begin{array}{r}-0.687 \\
0.005\end{array}$ & $\begin{array}{l}0.332 \\
0.171\end{array}$ \\
\hline 3. Hot Rolled Sheet & $\$ 344.44$ & $\$ 98.77$ & $\begin{array}{r}-0.542 \\
0.026\end{array}$ & $\begin{array}{r}-0.783 \\
0.001\end{array}$ & $\begin{array}{l}0.031 \\
0.897\end{array}$ & $\begin{array}{r}-0.076 \\
0.757\end{array}$ & $\begin{array}{l}0.258 \\
0.289\end{array}$ & $\begin{array}{r}-0.150 \\
0.535\end{array}$ & $\begin{array}{r}-0.688 \\
0.005\end{array}$ & $\begin{array}{l}0.273 \\
0.258\end{array}$ \\
\hline 4. Cold Rolled Sheet & $\$ 443.45$ & $\$ 105.84$ & $\begin{array}{r}-0.278 \\
0.250\end{array}$ & $\begin{array}{r}-0.687 \\
0.005\end{array}$ & $\begin{array}{l}0.295 \\
0.222\end{array}$ & $\begin{array}{l}0.150 \\
0.535\end{array}$ & $\begin{array}{l}0.506 \\
0.037\end{array}$ & $\begin{array}{r}-0.088 \\
0.719\end{array}$ & $\begin{array}{r}-0.716 \\
0.003\end{array}$ & $\begin{array}{l}0.472 \\
0.051\end{array}$ \\
\hline 5. Galvanized & $\$ 522.58$ & $\$ 135.83$ & $\begin{array}{r}-0.325 \\
0.180\end{array}$ & $\begin{array}{r}-0.632 \\
0.0099\end{array}$ & $\begin{array}{l}0.299 \\
0.219\end{array}$ & $\begin{array}{l}0.055 \\
0.818\end{array}$ & $\begin{array}{l}0.522 \\
0.032\end{array}$ & $\begin{array}{r}-0.070 \\
0.772\end{array}$ & $\begin{array}{r}-0.702 \\
0.004\end{array}$ & $\begin{array}{l}0.457 \\
0.060)\end{array}$ \\
\hline 6. Stainless & $\$ 1736.20$ & $\$ 483.07$ & $\begin{array}{l}0.299 \\
0.219\end{array}$ & $\begin{array}{r}-0.261 \\
0.280\end{array}$ & $\begin{array}{l}0.643 \\
0.008\end{array}$ & $\begin{array}{l}0.625 \\
0.010\end{array}$ & $\begin{array}{l}0.768 \\
0.001\end{array}$ & $\begin{array}{r}-0.082 \\
0.734\end{array}$ & $\begin{array}{r}-0.601 \\
0.013\end{array}$ & $\begin{array}{l}0.774 \\
0.001\end{array}$ \\
\hline 7. Cold Finished & $\$ 423.44$ & $\$ 97.98$ & $\begin{array}{l}0.000 \\
1.000\end{array}$ & $\begin{array}{r}-0.581 \\
0.016\end{array}$ & $\begin{array}{l}0.306 \\
0.208\end{array}$ & $\begin{array}{l}0.447 \\
0.066\end{array}$ & $\begin{array}{l}0.516 \\
0.033\end{array}$ & $\begin{array}{r}-0.154 \\
0.529\end{array}$ & $\begin{array}{r}-0.713 \\
0.003\end{array}$ & $\begin{array}{l}0.550 \\
0.023\end{array}$ \\
\hline 8. Reinforcing $\mathrm{Bar}$ & $\$ 335.54$ & $\$ 123.09$ & $\begin{array}{r}-0.631 \\
0.009\end{array}$ & $\begin{array}{r}-0.895 \\
0.000\end{array}$ & $\begin{array}{r}-0.198 \\
0.412\end{array}$ & $\begin{array}{r}-0.290 \\
0.230\end{array}$ & $\begin{array}{l}0.083 \\
0.734\end{array}$ & $\begin{array}{r}-0.124 \\
0.610\end{array}$ & $\begin{array}{r}-0.675 \\
0.005\end{array}$ & $\begin{array}{l}0.000 \\
1.000\end{array}$ \\
\hline 9. Wire Rod & $\$ 340.78$ & $\$ 107.51$ & $\begin{array}{r}-0.535 \\
0.027\end{array}$ & $\begin{array}{r}-0.819 \\
0.001\end{array}$ & $\begin{array}{r}-0.017 \\
0,944\end{array}$ & $\begin{array}{r}-0.278 \\
0.250\end{array}$ & $\begin{array}{l}0.215 \\
0.373\end{array}$ & $\begin{array}{r}-0.034 \\
0.889\end{array}$ & $\begin{array}{r}-0.609 \\
0.012\end{array}$ & $\begin{array}{r}-0.002 \\
0.992\end{array}$ \\
\hline $\begin{array}{l}\text { 10.Joint venture intensity } \\
\text { (number of JVs per firm) }\end{array}$ & 0.94 & 0.17 & $\begin{array}{l}1.000 \\
0.000\end{array}$ & $\begin{array}{l}0.632 \\
0.009\end{array}$ & $\begin{array}{l}0.693 \\
0.005\end{array}$ & $\begin{array}{l}0.499 \\
0.039\end{array}$ & $\begin{array}{l}0.535 \\
0.027\end{array}$ & $\begin{array}{l}0.403 \\
0.097\end{array}$ & $\begin{array}{l}0.358 \\
0.139\end{array}$ & $\begin{array}{l}0.249 \\
0.303\end{array}$ \\
\hline 11.Capacity (\% rate) & 76.71 & 12.10 & & $\begin{array}{l}1.000 \\
0.000\end{array}$ & $\begin{array}{l}0.329 \\
0.174\end{array}$ & $\begin{array}{l}0.245 \\
0.312\end{array}$ & $\begin{array}{l}0.062 \\
0.795\end{array}$ & $\begin{array}{l}0.380 \\
0.116\end{array}$ & $\begin{array}{l}0.676 \\
0.005\end{array}$ & $\begin{array}{r}-0.004 \\
0.984\end{array}$ \\
\hline $\begin{array}{l}\text { 12. Total Cost (direct labor } \\
\text { and material costs per ton) }\end{array}$ & $\$ 248.30$ & $\$ 58.41$ & & & $\begin{array}{l}1.000 \\
0.000\end{array}$ & $\begin{array}{l}0.505 \\
0.038\end{array}$ & $\begin{array}{l}0.920 \\
0.000\end{array}$ & $\begin{array}{l}0.356 \\
0.142\end{array}$ & $\begin{array}{l}0.032 \\
0.897\end{array}$ & $\begin{array}{l}0.597 \\
0.014\end{array}$ \\
\hline $\begin{array}{l}\text { 13.Integrated Cost (direct } \\
\text { labor and material costs } \\
\text { per ton) }\end{array}$ & $\$ 343.78$ & $\$ 83.63$ & & & & $\begin{array}{l}1.000 \\
0.000\end{array}$ & $\begin{array}{l}0.533 \\
0.028\end{array}$ & $\begin{array}{r}-0.295 \\
0.222\end{array}$ & $\begin{array}{r}-0.244 \\
0.312\end{array}$ & $\begin{array}{l}0.777 \\
0.001\end{array}$ \\
\hline $\begin{array}{l}\text { 14. Non-integrated Cost } \\
\text { (direct labor and } \\
\text { material costs per ton) }\end{array}$ & $\$ 152.82$ & $\$ 33.18$ & & & & & $\begin{array}{l}1.000 \\
0.000\end{array}$ & $\begin{array}{l}0.257 \\
0.289\end{array}$ & $\begin{array}{r}-0.243 \\
0.317\end{array}$ & $\begin{array}{l}0.630 \\
0.009\end{array}$ \\
\hline $\begin{array}{l}\text { 15. Imports (natural log of } \\
\text { imports in million tons) }\end{array}$ & $21.12 \mathrm{~m}$ & $1.25 \mathrm{~m}$ & & & & & & $\begin{array}{l}1.000 \\
0.000\end{array}$ & $\begin{array}{l}0.611 \\
0.012\end{array}$ & $\begin{array}{r}-0.227 \\
0.347\end{array}$ \\
\hline $\begin{array}{l}\text { 16.Demand (natural log of } \\
\text { shipment in million tons) }\end{array}$ & $100.48 \mathrm{~m}$ & $11.78 \mathrm{~m}$ & & & & & & & $\begin{array}{l}1.000 \\
0.000\end{array}$ & $\begin{array}{r}-0.432 \\
0.075\end{array}$ \\
\hline $\begin{array}{l}\text { 17. Substitute Price (mean } \\
\$ \text { price of competing } \\
\text { aluminum material) }\end{array}$ & $\$ 1654.00$ & $\$ 641.00$ & & & & & & & & $\begin{array}{l}1.000 \\
0.000\end{array}$ \\
\hline
\end{tabular}

*Price amounts are per short ton real prices in 1987 dollar. 
where Concentration Ratio Eight $\left(\mathrm{CR}_{8}\right)$-- combined market share of the leading eight steel producers was used to estimate the model and $\mathrm{CR}_{4}$ combined market share of the leading four steel producers, was used for robustness check. The alliance variable is defined as the average annual horizontal joint ventures per firm and capacity was estimated by the natural logarithm of the average annual rate of capacity utilization. Total costs were estimated by the natural logarithm of the average annual production costs (material inputs and labor) per ton of output; material costs by the natural logarithm of the average annual material input costs per ton of output; and labor costs by the natural logarithm of the average annual production workers' wages per ton of output. Table 3 following summarizes the data.

\section{Table 3 \\ Correlation matrix for the concentration model Dependent variable: Concentration ratio eight $(\mathrm{N}=\mathbf{2 0})$}

The first number represents estimated correlation, the second p-value under the hypothesis of zero correlation.

\begin{tabular}{|c|c|c|c|c|c|c|c|c|c|}
\hline & Mean* & S.D. & 1 & 2 & 3 & 4 & 5 & 6 & 7 \\
\hline 1. Concentration Ratio light & $57.2 \%$ & $15.2 \%$ & $\begin{array}{l}1.000 \\
0.000\end{array}$ & & & & & & \\
\hline 2. Concentration Ratio Four & $38.6 \%$ & $8.9 \%$ & $\begin{array}{l}0.812 \\
0.001\end{array}$ & $\begin{array}{l}1.000 \\
0.000\end{array}$ & & & & & \\
\hline $\begin{array}{l}\text { 3. Joint venture intensily (number of } \\
\text { joint ventures per firm) }\end{array}$ & 0.94 & 0.17 & $\begin{array}{r}-0.822 \\
0.001\end{array}$ & $\begin{array}{r}-0.953 \\
0.000\end{array}$ & $\begin{array}{l}1.000 \\
0.000\end{array}$ & & & & \\
\hline $\begin{array}{l}\text { 4. Capacity ( } 1 / \text { natural logarithm of } \\
\text { industry capacity utilization rate) }\end{array}$ & $76.71 \%$ & $12.10 \%$ & $\begin{array}{l}0.268 \\
0.125\end{array}$ & $\begin{array}{l}0.684 \\
0.003\end{array}$ & $\begin{array}{r}-0.576 \\
0.009\end{array}$ & $\begin{array}{l}1.000 \\
0.000\end{array}$ & & & \\
\hline $\begin{array}{l}\text { 5. Total Cost (natural logarithm of } \\
\text { anoual production costs per ton) }\end{array}$ & $\$ 248.30$ & $\$ 58.41$ & $\begin{array}{r}-0.648 \\
0.005\end{array}$ & $\begin{array}{r}-0.221 \\
0.169\end{array}$ & $\begin{array}{l}0.253 \\
0.137\end{array}$ & $\begin{array}{l}0.313 \\
0.091\end{array}$ & $\begin{array}{l}1.000 \\
0.000\end{array}$ & & \\
\hline $\begin{array}{l}\text { 6. Material Cost (natural } \\
\text { logarithm of annual raw } \\
\text { material costs per ton) }\end{array}$ & $\$ 198.69$ & $\$ 49.08$ & $\begin{array}{r}-0.685 \\
0.003\end{array}$ & $\begin{array}{r}-0.266 \\
0.126\end{array}$ & $\begin{array}{l}0.298 \\
0.100\end{array}$ & $\begin{array}{l}0.262 \\
0.130\end{array}$ & $\begin{array}{l}0.996 \\
0.000\end{array}$ & $\begin{array}{l}1.000 \\
0.000\end{array}$ & \\
\hline $\begin{array}{l}\text { 7. labor Cost (natural logarithm } \\
\text { of annual production Jabor costs) }\end{array}$ & $\$ 49.61$ & $\$ 11.14$ & $\begin{array}{r}-0.413 \\
0.042\end{array}$ & $\begin{array}{l}0.015 \\
0.944\end{array}$ & $\begin{array}{l}0.016 \\
0.944\end{array}$ & $\begin{array}{l}0.524 \\
0.015\end{array}$ & $\begin{array}{l}0.919 \\
0.000\end{array}$ & $\begin{array}{l}0.879 \\
0.000\end{array}$ & $\begin{array}{l}1.000 \\
0.000\end{array}$ \\
\hline
\end{tabular}

* Price amounts are per short ton real prices in 1987 dollar.

Table 3 indicates a mean $\mathrm{CR}_{8}$ of $57.2 \%$ and $\mathrm{CR}_{4}$ of $38.6 \%$. The table indicates highly correlated alliance intensity and capacity that in turn is correlated with production labor costs. A pair of models (a full model with the alliance and capacity variables and a reduced model without the capacity variable) was estimated for the three production cost categories to control for potential multicollinearity. 


\section{Results}

Tables 4 and 5 following provide regression results for the performance models. The profitability model (Table 4) shows a statistically significant F-statistics for the ROS measure although F-statistics for the ROA and ROE measures are not significant. Table 5 shows statistically significant F-statistics for the productivity and operating margin models. The tables indicate positive association between alliance intensity and industry profitability and productivity over the 1977-1997 period. Similarly, Table 4 indicates a positive association between new capital expenditure and industry ROA and ROS although Table 5 indicates a negative association between new capital expenditure and industry productivity. The intriguing association of capital investment with low productivity may be explained by the structure of the U.S. steel industry.

The 1990s saw heavy investment in capital equipment by the U.S. integrated steel producers that faced declining labor productivity due to entrenched labor

Table 4

Regression of trend of industry profitability on horizontal joint venturing $(\mathbf{N}=\mathbf{2 0})$

\begin{tabular}{|c|c|c|c|c|c|c|}
\hline \multirow{2}{*}{$\begin{array}{l}\text { Dependent Variable: } \\
\text { Independent } \\
\text { Variables }\end{array}$} & \multicolumn{2}{|c|}{ Return on assets } & \multicolumn{2}{|c|}{ Return on equity } & \multicolumn{2}{|c|}{ Return on sales } \\
\hline & $\begin{array}{l}\text { Parameter } \\
\text { estimate }\end{array}$ & $\begin{array}{c}t- \\
\text { statistic }\end{array}$ & $\begin{array}{l}\text { Parameter } \\
\text { estimate }\end{array}$ & $\begin{array}{c}t- \\
\text { statistic }\end{array}$ & $\begin{array}{l}\text { Parameter } \\
\text { estimate }\end{array}$ & $\begin{array}{c}\mathrm{t}- \\
\text { statistic }\end{array}$ \\
\hline$\beta_{0}:$ Intercept & -32.88 & $-2.36^{* *}$ & -228.73 & $-2.18 * *$ & -31.52 & $-2.68^{* *}$ \\
\hline $\begin{array}{l}\beta_{1}: \text { Lagged industry returns } \\
\left(\mathrm{ROA}_{t-1}, \mathrm{ROE}_{\mathrm{t}-1}, \text { and } \mathrm{ROS}_{\mathrm{t}-1}\right)\end{array}$ & 0.07 & 0.30 & -0.17 & -0.69 & 0.03 & 0.13 \\
\hline $\begin{array}{l}\beta_{2}: \text { Lagged joint venture } \\
\text { intensity (number of } \\
\text { horizontal joint ventures } \\
\text { per firm) }\end{array}$ & 28.46 & $2.56^{* *}$ & 185.11 & $2.18^{* *}$ & 26,65 & $2.87^{* *}$ \\
\hline $\begin{array}{l}\beta_{3}: \text { Lagged industry new } \\
\text { capital expenditure/Sales }\end{array}$ & 3.83 & $2.11^{*}$ & 23.45 & 1.71 & 3.43 & $2.30^{* *}$ \\
\hline $\begin{array}{l}\beta_{4} \text { : Lagged acquisitions } \\
\text { (natural logarithm of number } \\
\text { of horizontal mergers and } \\
\text { acquisitions) }\end{array}$ & -3.52 & -1.74 & -12.74 & -0.82 & -2.51 & -1.52 \\
\hline Adjusted $\mathrm{R}^{2}$ & & 0.18 & & 0.06 & & 0.24 \\
\hline F-Value for regression & & 2.06 & & 1.29 & & $2.53^{*}$ \\
\hline Durbin-Watson statistic & & $1.61+$ & & $1.88+$ & & $1.64+$ \\
\hline
\end{tabular}

**Parameter is significantly different from zero at the $5 \%$ level, using a two-tailed test.

* Parameter is significantly different from zero at the $10 \%$ level, using a two-tailed test.

+ Statistical indications that the time series data are not autocorrelated at $\alpha=0.01$ significance level. 
unions and high legacy costs (S\&P, July 1999 Industry Survey). On the other hand, minimill producers enjoyed high labor productivity but had limited capital investment (S\&P, January 2002 Industry Survey). Therefore, interaction between the integrated producer's high capital expenditure-low productivity characteristic and the minimill's low capital expenditure-high productivity characteristic may have confounded the true capital expenditure-productivity relationship. Table 5 also shows a negative acquisition coefficient in the operating margin model indicating that horizontal acquisitions may have temporal negative impact on industry operations. Tables 6,7 , and 8 provide results for the industry structure models.

Table 6 provides regression results for the nine steel product prices. All the nine models exhibited significant $F$-statistics and relatively independent residuals. $\mathrm{R}^{2}$ (adjusted) for the full model indicates that variability in alliance intensity, input costs, capacity, and demand trends accounted for $61 \%$ to $89 \%$ of variability in the trend of real price (1987 dollar) of steel products. In all but three products, the full model exhibited statistically significant negative coefficients for the alliance variable. Table 6 shows that all else equal, a $1 \%$ increase in horizontal alliance intensity was followed by a $0.6 \%$ drop in steel beam prices, a $0.8 \%$ drop in HotRolled Sheet prices, $0.5 \%$ drop in Cold-Rolled Sheet prices, and a $1 \%$ drop in Galvanized steel prices. It also shows that a $1 \%$ increase in alliance intensity was followed by a $0.7 \%$ drop in reinforcing bar prices and a $0.6 \%$ drop in wire rod prices. The following section discusses the parallels between these results and the structure of the steel industry.

\section{Steel producers versus processors}

Table 6 indicates statistically insignificant alliance coefficients for processor products, Cold Finished and Stainless steel in the full model, although the coefficients are positive and statistically significant in the reduced models. That is, for steel processors or Maximills, horizontal alliances were followed by increase in real prices as opposed to the declining prices of integrated and minimill products. The opposite behavior of processor prices is consistent with the industry structure. Unlike steel producers, steel processors mainly add value to producer products by focusing on difficult steel applications. Thus primary production capacity has no impact on processor prices and processors can maintain profits even when primary (integrated and minimill) producers are unprofitable. For instance, processors can profit through tolling (treating customers' steel for a fee) even when primary producers resort to price cuts. Since steel producers supply the processors, alliances that enhance primary producers' capabilities to complete difficult applications reduce tolling opportunities for steel processors. Without tolling opportunities and facing competitive pressure from producers that had integrated downstream into difficult applications, steel processors may have found price hikes to be the only avenue for survival. Thus, horizontal alliances that enhance steel producers' capabilities also enable them to encroach into the processor domain thereby squeezing processor margins and compelling price hikes among processors. The following section links the results to the structure of the producer segment. 
Table 5

Regression of trends of industry productivity and operating margin on horizontal joint venturing $(\mathrm{N}=\mathbf{2 0})$

\begin{tabular}{|c|c|c|c|c|c|}
\hline \multicolumn{3}{|l|}{ Productivity Model } & \multicolumn{3}{|l|}{ Operating Margin Model } \\
\hline Independent Variables & $\begin{array}{l}\text { Parameter } \\
\text { estimate }\end{array}$ & $\begin{array}{c}t- \\
\text { statistic }\end{array}$ & Independent Variables & $\begin{array}{l}\text { Parameter } \\
\text { estimate }\end{array}$ & $\begin{array}{c}\mathrm{t}- \\
\text { statistic }\end{array}$ \\
\hline$\beta_{0}:$ Intercept & 3.20 & $10.19^{* * *}$ & $\beta_{t i}$ : Intercept & -9.92 & -1.66 \\
\hline $\begin{array}{l}\beta_{1} \text { : Lagged joint venture } \\
\text { intensity (number of } \\
\text { horizontal joint ventures } \\
\text { per firm) }\end{array}$ & 1.26 & $4.93^{* * *}$ & $\begin{array}{l}\beta, \text { Lagged operating } \\
\text { margin (\%) }\end{array}$ & 0.46 & $2.08^{*}$ \\
\hline $\begin{array}{l}\beta_{2}: \text { Lagged industry new } \\
\text { capital expenditure/Sales }\end{array}$ & -0.12 & $-2.92^{* * *}$ & $\begin{array}{l}\beta_{2}: \text { Lagged joint venture } \\
\text { intensity (number of } \\
\text { horizontal joint ventures } \\
\text { per firm) }\end{array}$ & 15.72 & $3.20^{* * *}$ \\
\hline \multirow{2}{*}{$\begin{array}{l}\beta_{3}: \text { Lagged acquisitions } \\
\text { (natural log of number of } \\
\text { horizontal mergers \& } \\
\text { acquisitions) }\end{array}$} & -0.03 & -0.73 & $\begin{array}{l}\beta_{5}: \text { Lagged industry new } \\
\text { capital expenditure/Sales }\end{array}$ & 1.44 & 1.66 \\
\hline & & & $\begin{array}{l}\beta_{1} \text { : Lagged acquisitions } \\
\text { (natural log of number of } \\
\text { horizontal mergers \& } \\
\text { acquisitions) }\end{array}$ & -2.01 & $-2.23 * *$ \\
\hline Adjusted $\mathrm{R}^{2}$ & & 0.81 & Adjusted $\mathrm{R}^{2}$ & & 0.41 \\
\hline F-Value for regression & & $27.49 * * *$ & F-Value for regression & & $4.36^{* *}$ \\
\hline Durbin-Watson statistic & & $1.56+$ & Durbin-Watson statistic & & $1.86+$ \\
\hline
\end{tabular}

*** Parameter is significantly different from zero at the $1 \%$ level, using a two-railed test.

** Parameter is significantly different from zero at the 5\% level, using a two-lailed test.

* Parameter is significantly different from zero at the $10 \%$ level, using a two-lailed test.

+ Statistical indications that the lime series data are not autocorrelated at $\alpha=0.01$ significance level.

\section{Integrated versus minimill producers}

Table 6 also indicates that horizontal alliances had greatest impact on the price of galvanized steel and hot-rolled sheet --the most lucrative of the integrated product segments and the least contested by domestic minimills. A cursory view of the raw data reveals that a large number of alliances between foreign competitors and integrated producers entailed galvanization process and the hot-rolled sheet category.' Horizontal alliances thus induced competition in the integrated 
Table 6

Two-Stage Least Squares Regression of the trend of steel products prices, horizontal alliances, and industry costs -Demand is instrumented with imports, substitute price, and the steel product price $(\mathrm{N}=20)$

\begin{tabular}{|c|c|c|c|c|c|c|}
\hline \multirow{3}{*}{$\begin{array}{l}\text { Dependent variable: } \\
\text { Independent variables }\end{array}$} & \multicolumn{6}{|c|}{ Beams (Natural logarithm of price per ton) } \\
\hline & \multicolumn{2}{|c|}{ (Full model) } & \multicolumn{2}{|c|}{ (Reduced model-JVI) } & \multicolumn{2}{|c|}{ (Reduced model-Costs) } \\
\hline & $\begin{array}{c}\text { Parameter } \\
\text { estimate }\end{array}$ & $\begin{array}{c}\mathrm{t}- \\
\text { statistic }\end{array}$ & $\begin{array}{c}\text { Parameter } \\
\text { estimate }\end{array}$ & $\begin{array}{c}t- \\
\text { statistic }\end{array}$ & $\begin{array}{l}\text { Parameter } \\
\text { estimate }\end{array}$ & $\begin{array}{c}\text { 1- } \\
\text { statistic }\end{array}$ \\
\hline Intercept & 10.57 & $6.99 * * *$ & 15.12 & $12.78^{* * *}$ & 15.94 & $9.9[* * *$ \\
\hline Joint venture intensity & -0.60 & $-2.78 * *$ & -0.19 & -1.14 & & \\
\hline Production costs & 0.61 & $2.98^{* * *}$ & & & -0.06 & -0.45 \\
\hline Capacity & -0.19 & -0.62 & & & & \\
\hline Demand & -1.11 & $-2.60^{* *}$ & -1.96 & $-7.46^{* * *}$ & -2.10 & $-7.49 * * *$ \\
\hline Adjusted $\mathrm{R}^{2}$ & & 0.85 & & 0.74 & & 0.71 \\
\hline F-Value for regression & & $28.13 * * *$ & & $32.23^{* * *}$ & & $28.67 * * *$ \\
\hline Durbin-Watson statistic & & $2.15+$ & & $1.94+$ & & $2.06+$ \\
\hline \multicolumn{7}{|c|}{ Dependent variable: Steel Plates } \\
\hline Intercept & 6.59 & $3.14 * * *$ & 13.38 & $7.60 * * *$ & 14.58 & $5.82 * * *$ \\
\hline Joint venture intensity & -0.34 & -1.15 & -0.02 & -0.09 & & \\
\hline Production costs & 0.76 & $2.65^{* *}$ & & & -0.17 & -0.75 \\
\hline Capacity & -0.90 & $-2.12^{*}$ & & & & \\
\hline Demand & 0.28 & 0.48 & -1.60 & $-4.11 * * *$ & -1.65 & $-4.29 * * *$ \\
\hline Adjusted R² & & 0.63 & & 0.37 & & 0.38 \\
\hline F-Value for regression & & $9.26^{* * *}$ & & $9.10^{* * *}$ & & $9.29 * * *$ \\
\hline Durbin-Watson statistic & & 1.28 & & $1.31+$ & & $1.38+$ \\
\hline \multicolumn{7}{|c|}{ Dependent variable: Hot Rolled Sheet } \\
\hline Intercept & 5.24 & $2.78 * *$ & 14.08 & $7.26 * * *$ & 15.45 & $6.16 * * *$ \\
\hline Joint venture intensity & -0.80 & $-3.00^{*}$ & -0.24 & -0.92 & & \\
\hline Production costs & 1.07 & $4.17 * * *$ & & & -0.14 & -0.75 \\
\hline Capacity & -0.95 & $-2.50 * *$ & & & & \\
\hline Demand & 0.49 & 0.91 & -1.74 & $-4.05 * * *$ & -1.91 & $-4.34 * * *$ \\
\hline Adjusted $\mathrm{R}^{2}$ & & 0.78 & & 0.42 & & 0.39 \\
\hline F-Value for regression & & $18.21 * * *$ & & $10.16 * * *$ & & $9.41^{* * *}$ \\
\hline Durbin-Watson statistic & & $1.59+$ & & $1.37+$ & & $1.48+$ \\
\hline
\end{tabular}

*** Parameter is significantly different from zero at the $1 \%$ level, using a two-tailed test.

** Parameter is significantly different from zero at the $5 \%$ level, using a two-lailed test.

* Parameter is significantly difterent from zero at the $10 \%$ level, using a two-tailed test.

- Inconclusive evidence for autocorrelation in the time series data al $\alpha=0.01$ significance level.

+ Statistical indications that the time series data are not autocorrelated at $\alpha=0.01$ significance level. 


\section{Table 6 Continued}

Two-Stage Least Squares Regression of the trend of steel products prices, horizontal alliances, and industry costs -Demand is instrumented with imports, substitute price, and the steel product price $(\mathrm{N}=\mathbf{2 0})$

\begin{tabular}{|c|c|c|c|c|c|c|}
\hline \multirow{3}{*}{$\begin{array}{l}\text { Dependent variable: } \\
\text { Independent variables }\end{array}$} & \multicolumn{6}{|c|}{ Cold-Rolled Sheet (Natural logarithm of price per ton) } \\
\hline & \multicolumn{2}{|c|}{ (Full model) } & \multicolumn{2}{|c|}{ (Reduced model-JVI) } & \multicolumn{2}{|c|}{ (Reduced model-Costs) } \\
\hline & $\begin{array}{c}\text { Parameter } \\
\text { estimate }\end{array}$ & $\begin{array}{c}t- \\
\text { statistic }\end{array}$ & $\begin{array}{c}\text { Parameter } \\
\text { estimate }\end{array}$ & $\stackrel{t-}{\text { statistic }}$ & $\begin{array}{l}\text { Parameter } \\
\text { estimate }\end{array}$ & $\begin{array}{c}\mathrm{t}- \\
\text { statistic }\end{array}$ \\
\hline Intercept & 6.71 & $4.44 * * *$ & 13.70 & $8.32 * * *$ & 12.55 & $6.23^{* * *}$ \\
\hline Joint venture intensity & -0.49 & $-2.04 * *$ & 0.15 & 0.70 & & \\
\hline Production costs & 0.87 & $4.79 * * *$ & & & 0.12 & 0.81 \\
\hline Capacity & -0.76 & -2.25 & & & & \\
\hline Demand & -0.18 & -0.39 & -1.68 & $-4.60 * * *$ & -1.56 & $-4.41 * * *$ \\
\hline Adjusted $\mathrm{R}^{2}$ & & 0.78 & & 0.43 & & 0.46 \\
\hline F-Value for regression & & $18.04 * * *$ & & $10.68^{* * *}$ & & $11.31^{* * *}$ \\
\hline Durbin-Watson statistic & & $1.97+$ & & $1.40+$ & & $1.28+$ \\
\hline
\end{tabular}

Dependent variable: Galvanized Steel

\begin{tabular}{|c|c|c|c|c|c|c|}
\hline Intercept & 8.07 & $4.65 * * *$ & 14.56 & $7.65^{* * *}$ & 14.43 & $6.10^{* * *}$ \\
\hline Joint venture intensity & -0.95 & $-3.69 * * *$ & 0.04 & 0.16 & & \\
\hline Production costs & 0.99 & $4.69 * *$ & & & -0.002 & -0.01 \\
\hline Capacity & NA & NA & & & & \\
\hline Demand & -1.18 & $-4.08^{* * *}$ & -1.81 & $-4.29 * * *$ & -1.77 & $-4.28 * * *$ \\
\hline Adjusted $\mathrm{R}^{2}$ & & 0.76 & & 0.40 & & 0.41 \\
\hline F-Value for regression & & $22.56^{* * *}$ & & $9.62^{* * *}$ & & $9.56^{* * *}$ \\
\hline Durbin-Watson statistic & & $1.68+$ & & 1.04 & & 1.00 \\
\hline \multicolumn{7}{|c|}{ Dependent variable: Stainless Sheet } \\
\hline Intercept & 13.89 & $6.03^{* * *}$ & 17.86 & $8.94 * * *$ & 12.11 & $6.95^{* * *}$ \\
\hline Joint venture intensity & 0.50 & 1.48 & 1.09 & $4.19 * * *$ & & \\
\hline Production costs & 0.74 & $2.71 * *$ & & & 1.05 & $5.73^{* * *}$ \\
\hline Capacity & $\mathrm{NA}$ & NA & & & & \\
\hline Demand & -2.24 & $-5.76 * * *$ & -2.47 & $-5.57 * * *$ & -2.05 & $-6.04 * * *$ \\
\hline Adjusted $\mathrm{R}^{2}$ & & 0.74 & & 0.59 & & 0.74 \\
\hline F-Value for regression & & $22.01 * * *$ & & $19.69^{* * *}$ & & $33.45 * * *$ \\
\hline Durbin-Watson statistic & & $2.11+$ & & $1.43+$ & & $2.09+$ \\
\hline
\end{tabular}

*** Parameter is significantly different from zero at the $1 \%$ level, using a two-tailed test.

**Parameter is significantly different from zero at the 5\% level, using a two-tailed test.

*Parameter is significantly different from zero at the $10 \%$ level, using a two-tailed test.

$\sim$ Inconclusive evidence for autocorrelation in the time series data at $\alpha=0.01$ significance level.

+ Statistical indications that the time series data are not autocorrelated at $\alpha=0.01$ significance level. 


\section{Table 6 Continued}

Two-Stage Least Squares Regression of the trend of steel products prices, horizontal alliances, and industry costs -Demand is instrumented with imports, substitute price, and the steel product price $(\mathrm{N}=20)$

\begin{tabular}{|c|c|c|c|c|c|c|}
\hline \multirow{3}{*}{$\begin{array}{l}\text { Dependent variable: } \\
\text { Independent variables }\end{array}$} & \multicolumn{6}{|c|}{ Cold-Finished Steel (Natural logarithm of price per ton) } \\
\hline & \multicolumn{2}{|c|}{ (Full model) } & \multicolumn{2}{|c|}{ (Reduced model-JVI) } & \multicolumn{2}{|c|}{ (Reduced model-Costs) } \\
\hline & $\begin{array}{c}\text { Parameter } \\
\text { estimate }\end{array}$ & $\begin{array}{c}t- \\
\text { statistic }\end{array}$ & $\begin{array}{l}\text { Parameter } \\
\text { estimate }\end{array}$ & $\begin{array}{c}t- \\
\text { statistic }\end{array}$ & $\begin{array}{l}\text { Parameter } \\
\text { estimate }\end{array}$ & $\begin{array}{c}\mathrm{t}- \\
\text { statistic }\end{array}$ \\
\hline Intercept & 8.03 & $5.79 * * *$ & 13.94 & $9.15^{* * *}$ & 11.91 & $7.25 * * *$ \\
\hline Joint venture intensity & 0.34 & 1,10 & 0.43 & $2,14^{* *}$ & & \\
\hline Production costs & 0.59 & $2.22^{* * *}$ & & & 0.37 & $2.14^{* *}$ \\
\hline Capacity & NA & $\mathrm{NA}$ & & & & \\
\hline Demand & -0.94 & $-3.76^{* * *}$ & -1.80 & $-5.32 * * *$ & -1.64 & $-5.16 * * *$ \\
\hline Adjusted $\mathrm{R}^{2}$ & & 0.61 & & 0.51 & & 0.54 \\
\hline F-Value for regression & & $10.70^{* * *}$ & & $\left.14.5\right|^{* * *}$ & & $15.25 * * *$ \\
\hline Durbin-Watson statistic & & 1.20 & & $1.86+$ & & $1.66+$ \\
\hline
\end{tabular}

Dependent variable: Reinforcing Bar

\begin{tabular}{|c|c|c|c|c|c|c|}
\hline Intercept & 5.71 & $3.26^{* * *}$ & 14.91 & $6.78 * * *$ & 16.55 & $5.47^{* * *}$ \\
\hline Joint venture intensity & -0.65 & $-2.60^{* *}$ & -0.55 & $-1.79 *$ & & \\
\hline Production costs & 0.98 & $4.14 * * *$ & & & -0.24 & -0.60 \\
\hline Capacity & -2.09 & $-5.90^{* * * *}$ & & & & \\
\hline Demand & 1.47 & $2.96^{* *}$ & -1.87 & $-3.84 * * *$ & -2.19 & $-4.03 * * *$ \\
\hline Adjusted $\mathrm{R}^{2}$ & & 0.89 & & 0.49 & & 0.39 \\
\hline F-Value for regression & & $38.24 * * *$ & & $11.21^{* * *}$ & & $8.24 * * *$ \\
\hline Durbin-Watson statistic & & $2.54+$ & & $0.88 \sim$ & & 0.89 \\
\hline \multicolumn{7}{|c|}{ Dependent variable: Wire Rod } \\
\hline Intercept & 4.15 & $2.54^{* *}$ & 13.19 & $6.04 * * *$ & 13.14 & $4.66^{* * *}$ \\
\hline Joint venture intensity & -0.60 & $-2.34 * * *$ & -0.30 & -1.01 & & \\
\hline Production cosis & 0.93 & $4.77^{* * *}$ & & & 0.08 & 0.21 \\
\hline Capacity & -2.04 & $-5.58 * * *$ & & & & \\
\hline Demand & 1.48 & $3.03 * * *$ & -1.54 & $-3.19 * * *$ & -1.64 & $-3.24 * * *$ \\
\hline Adjusted $R^{2}$ & & 0.84 & & 0.34 & & 0.29 \\
\hline F-Value for regression & & $26.11 * * *$ & & $6.75 * * *$ & & $5.87^{* *}$ \\
\hline Durbin-Watson statistic & & $2.02+$ & & 0.96 & & $0.93 \alpha$ \\
\hline
\end{tabular}

***Parameter is significantly different from zero at the $1 \%$ level, using a two-tailed test.

**Parameter is significantly different from zero at the $5 \%$ level, using a two-tailed test.

* Parameter is significantly different from zero at the $10 \%$ level, using a two-tailed test.

$\sim$ Inconclusive evidence for autocorrelation in the time series data at $\alpha=0.01$ significance level.

+ Statistical indications that the time series data are not autocorrelated at $\alpha=0.01$ significance level. 
Table 7

Two-Stage Least Squares Regression: The Differential Impact of Horizontal

Alliances on the Integrated and Minimill Steel Prices-Demand is instrumented with imports, substitute price, and the steel product price

$(\mathrm{N}=147)$

Dependent variable: Integrated and Minimill Steel Products (Natural logarithm of price per ton)

\begin{tabular}{lcc}
\hline Independent variables & Parameter estimate & t-statistic \\
\hline $\begin{array}{l}\text { Intercept } \\
\text { Joint venture intensity (number of J Vs per firm) }\end{array}$ & 4.65 & $4.65^{* * *}$ \\
$\begin{array}{l}\text { Production costs (Natural logarithm of direct labor and } \\
\text { material costs minus average costs per ton) }\end{array}$ & -0.04 & $2.85^{* * *}$ \\
$\begin{array}{l}\text { Capacity (Natural logarithm of production capacity } \\
\text { utilization rate minus average capacity utilization rate) }\end{array}$ & -2.21 & $-1.78^{*}$ \\
$\begin{array}{l}\text { Demand (Instrumented with the natural logarithm of: } \\
\text { shipment and imports in million tons and the natural } \\
\text { logarithm of product and substitute prices per ton) }\end{array}$ & & $-2.20^{* * *}$ \\
Adjusted R2 & -0.06 & -0.55 \\
\begin{tabular}{l} 
F-Value for regression \\
\hline
\end{tabular} & & 0.16 \\
\hline
\end{tabular}

*** Parameter is significantly different from zero at the $1 \%$ level, using a one-tailed test.

** Parameter is significantly different from zero at the $5 \%$ level, using a une-tailed test.

* Parameter is significantly different from zero at the $10 \%$ level, using a one-tailed test.

segments that hitherto experienced minimal competitive pressures. The Table indicates moderate alliance impact on the minimill-infiltrated beams segment and the minimill domain (rebar and wire rods) in consistence to competitive dynamics in these segments. Horizontal alliance impact on steel pricing trends therefore mirrors the minimill induced pressures on steel prices such as these producers entry into the steel beam segment that dipped beam prices by $\$ 70$ to $\$ 80$ a ton (Iron Age, August 1993:19).

Table 6 also indicates a statistically significant capacity coefficient that switches with the demand coefficient that might indicate a multicollinearity problem in the models (Neter, Wasserman, and Kutner, 1990). Alternatively, such switching might mean that integrated producers responded to declining demand by contracting output. If multicollinearity caused such switches, then both minimill and integrated product prices would exhibit similar patterns. However, if the switches resulted from differential producer response to demand fluctuations, 
then minimills would exhibit a different pattern since these producers' response to demand fluctuations differs from the integrated response. The table indicates statistically significant positive demand coefficients and negative capacity coefficients with t-statistics above the critical " 2 " (Kennedy, 1992) for the minimill products. That is, minimill producers may have responded to demand fluctuations through flexprice, hence the exhibited positive relationship between the trends of demand and price and a negative relationship between the trends of capacity utilization and price. Further, minimills' capacity utilization coefficients are more than double those of the integrated potentially indicating that minimills passed on efficiency gains from increased capacity utilization to their customers more than their integrated counterparts.

The lack of statistical significance of the capacity coefficient in some models could also result from the way demand and capacity variables were measured. Demand and capacity utilization variables for individual steel products were estimated by industry demand and capacity utilization. Yet, demand for individual products may not correspond to the average industry demand. Also, the use of the price of aluminum as a universal substitute proxy for all steel products may have interfered with the instrumental role of the price of substitutes variable in estimating the demand for products for which aluminum is not a substitute. Similarly, the amalgamated industry capacity utilization rate may vary significantly from the real capacity utilization rate for different products. The industry capacity utilization rate may also have less relevance to certain products besides cold-finished, galvanized, and stainless steel. Table 7 following explores further the differential impact of alliances on the producers.

Table 7 provides results of a cross sectional 2SLS regression model of steel prices with the five integrated products collapsed into one category and the two minimill products collapsed into a second category (integrated category $=1$ and minimill category $=0$ ). This model attempts to tease out the differential impact of horizontal alliances on the producers. Therefore, our focus is the direction rather than the actual value of estimated coefficients. However, we mean-centered the costs and capacity variables into deviation scores from their respective means before performing the regression analyses (Aiken and West, 1991). This remedial action reduces potential multicollinearity from the previously noted inter-correlations and increases chances of obtaining unbiased estimates of the alliance, costs, and capacity coefficients. The demand variable was not mean-centered since the modeled demand was instrumented with the imports and substitute price. Table 7 indicates that alliance intensity had greater impact on integrated steel prices than on minimill steel prices. This could indicate that the integrated segment adopted more horizontal alliances than the minimills - perhaps with foreign competitors seeking entry into this lucrative segment. Similarly, integrated producers did not appear to pass efficiency gains (lower production costs or efficient use of production capacity) to customers through lower prices as the minimills. Following is a discussion of the impact of horizontal alliances on industry concentration. 


\section{Steel industry concentration}

Table 8 provides regression results for the industry concentration models. All the models exhibited significant $\mathrm{F}$-statistics and relatively independent residuals. Save for potential autocorrelation, the reduced (JVI only) and full (JVI and capacity) models exhibit similar explanatory power for the trends of $\mathrm{CR}_{8}$ for all production cost categories. However, the full model offers a slightly better explanation for the trends of $\mathrm{CR}_{4}$. The alliance coefficient is negative and statistically significant in both models for all production cost categories although it is almost 20 percent larger with labor cost in the $\mathrm{CR}_{8}$ model. The cost coefficient is also negative and statistically significant in the $\mathrm{CR}_{8}$ model but insignificant in the $\mathrm{CR}_{4}$ model while the capacity coefficient is insignificant in the $\mathrm{CR}_{\mathrm{g}}$ model but significant in the $\mathrm{CR}_{4}$ model. These results suggest a general use of horizontal alliances in managing high costs in all segments but a specific focus on horizontal alliances for increasing capacity utilization among major or integrated producers (most of whose market share constitute) the $\mathrm{CR}_{4}$ measure. The results render support to the idea that horizontal alliances may have reduced industry concentration.

\section{Conclusion}

The study examined the impact of horizontal alliances on the U.S. steel industry's competitive structure and found indications of positive impacts on industry competitiveness (profitability and productivity) and indications of declining prices and industry concentration. While non-modeled factors may also influence industry performance and competitive structure, the indicated link with horizontal alliances is consistent with the capability hypothesis that steel firms may have adopted horizontal alliances in pursuit of capabilities rather than market power alone. A capability hypothesis encompasses dual motives. That is, firms may adopt horizontal alliances in the quest for competitive and cooperative advantages simultaneously (Lado, Boyd, and Hanlon, 1997) and that competitive needs may dictate the dominant motive. For instance, steel producers may have found horizontal alliances efficacious for monopoly pursuits in the insulated markets of mid-twentieth century (Fusfeld, 1958) but market power may not have been the main motivator two decades later (Berg and Friedman, 1978). It is likely that the increasingly open and competitive markets of the later decades made the quest for capabilities a dominant motive among domestic alliance contenders. The following section discusses horizontal alliances in the context of excess capacity

\section{Horizontal Alliances and Excess Capacity}

The results indicate that despite its potential to increase capacity, steel producers adopted horizontal alliances in the face of worldwide excess capacity. ${ }^{2}$ Such seeming contradiction is better understood by reviewing the condition of the U.S. steel industry at the time of these alliances. The U.S. steel market became the focal point of the transitioning and emerging economies' producers in 1990s. Yet, major domestic producers' diversification response to dwindling demand in the 
Table 8

Regression of trend of steel industry concentration on horizontal joint venturing $(\mathrm{N}=\mathbf{2 0})$

\begin{tabular}{|c|c|c|c|c|c|c|c|c|}
\hline \multirow{3}{*}{$\begin{array}{l}\text { Dependent variable: } \\
\text { Model Type }\end{array}$} & \multicolumn{4}{|c|}{ Concentration Ratio Eight (CR8) } & \multicolumn{4}{|c|}{ Concentration Ratio Four (CR4) } \\
\hline & \multicolumn{2}{|c|}{ (JVI \& Cap. U) } & \multicolumn{2}{|l|}{ (JVI only) } & \multicolumn{2}{|c|}{ (JVI \& Cap. U) } & \multicolumn{2}{|c|}{ (JVI only) } \\
\hline & Parameter estimate & t-statistic & Parameter estimate & t-statistic & Parameter estimate & t-statistic & Parameter estimate & t-statistic \\
\hline \multicolumn{9}{|c|}{ Independent variables (Total costs) } \\
\hline Intercept & 2.74 & $9.73^{* * *}$ & 2.73 & $10.07^{* * *}$ & 0.83 & $7.52^{* * *}$ & 0.78 & $5.74 * * *$ \\
\hline Joint venture intensity & -0.58 & $-5.65 * * *$ & -0.59 & $-8.47 * * *$ & -0.36 & $-8.96 * * *$ & -0.45 & $-12.98 * * *$ \\
\hline Total production costs & -0.28 & $-4.59 * * *$ & -0.28 & $-5.66^{* * *}$ & -0.04 & -1.62 & 0.01 & 0.29 \\
\hline Capacity & -0.01 & -0.18 & & & -0.09 & $-3.29 * *$ & & \\
\hline Adjusted R2 & & 0.86 & & 0.87 & & 0.93 & & 0.90 \\
\hline F-Value for regression & & $43.17 * * *$ & & $68.42^{* * *}$ & & $95.33 * * *$ & & $89.07 * * *$ \\
\hline Durbin-Watson statistic & & $0.85 \sim$ & & $0.84-$ & & $1.27 \sim$ & & $1.33+$ \\
\hline \multicolumn{9}{|c|}{ Independent variables (Material input costs) } \\
\hline Intercept & 2.61 & $10.49 * * *$ & 2.60 & $10.80^{* * *}$ & 0.80 & $8.01 * * *$ & 0.79 & $6.37 * * *$ \\
\hline Joint venture intensity & -0.57 & $-5.59 * * *$ & -0.57 & $-8.24 * * *$ & -0.36 & $-8.83^{* * *}$ & -0.46 & $-12.81 * * *$ \\
\hline Material input costs & -0.27 & $-4.77 * * *$ & -0.27 & $-5.86 * * *$ & -0.03 & -1.52 & 0.01 & 0.27 \\
\hline Capacity & -0.00 & -0.07 & & & -0.09 & $-3.22 *$ & & \\
\hline Adjusted $R^{2}$ & & 0.87 & & 0.88 & & 0.93 & & 0.90 \\
\hline F-Value for regression & & $45.30^{* * *}$ & & $71.92 * * *$ & & $93.77^{* * *}$ & & $89.02 * * *$ \\
\hline Durbin-Watson statistic & & 0.86 & & $0.85-$ & & $1.26 \sim$ & & $1.33+$ \\
\hline \multicolumn{9}{|c|}{ Independent variables (Labor input costs) } \\
\hline Intercept & 2.35 & $8.24 * * *$ & 2.35 & $8.54 * * *$ & 0.81 & $8.75 * * *$ & 0.77 & $6.65 * * *$ \\
\hline Joint venture intensity & -0.68 & $-5.96 * * *$ & -0.69 & $-8.56 * * *$ & -0.37 & $-9.92 * * *$ & -0.45 & $-13.39 * * *$ \\
\hline Labor input costs & -0.27 & $-3.17^{*}$ & -0.27 & $-4.19 * * *$ & -0.05 & -1.81 & 0.01 & 0.43 \\
\hline Capacity & -0.01 & -0.12 & & & -0.10 & $-3.40^{* *}$ & & \\
\hline Adjusted $\mathrm{R}^{2}$ & & 0.81 & & 0.82 & & 0.94 & & 0.90 \\
\hline F-Value for regression & & $29.00^{* * *}$ & & $46.02 * * *$ & & $98.75^{* * *}$ & & $89.63^{* * *}$ \\
\hline Durbin-Watson statistic & & 0.85 & & $0.83-$ & & $1.34 \sim$ & & $1.32+$ \\
\hline
\end{tabular}

***sig $@ 0.1 \% ; *$ sig $@ 0.5 \% ;{ }^{*} \operatorname{sig} @ 1 \%$ (two-tailed test)

- Statistical indications that the time series data may be autocorrelated at $\alpha=0.01$ significance level.

$\sim$ Inconclusive evidence for autocorrelation in the time series data at $\alpha=0.01$ significance level.

+ Statistical indications that the time series data are not autocorrelated at $\alpha=0,01$ significance level 
seventies had eroded capital resources for investment in steel production (Acs, 1984; Scheuerman, 1986). Therefore, domestic facilities contrasted sharply with the modern facilities of foreign producers such as the German and the Japanese (Lieberman and Johnson, 1995). At home, the waning steel influence, large legacy costs, pressure from efficient minimills, and the flooded global market compounded the integrated producers' woes. However, integrated producers attempts to close the capability gap were bogged by the costly to run old coke ovens that were expensive to rebuild and that produced harmful emissions into the environment. Individual producers found required investment for equipment replacement to be overwhelming leading to persistent calls for collaborative efforts to hasten resource mobilization within the industry (a common theme in the 1982-1992 issues of AISI's Iron Age publication).

In 1986 for instance, even the giants U.S. Steel and Bethlehem Steel had to solicit the U.S. Department of Energy for capital for the joint 'Hazelett StripCasting' project. As producers scrambled to reorganize, a series of tariffs and voluntary restraint agreements sprang up to hold the tide against cheap imports. The restrictions are believed to have contributed to import reduction by as much as twenty percent from $1992 .^{3}$ However, the pressure on steel imports pushed foreign producers to seek direct investment that could sidestep tariffs. Thus, foreign producers sought entry into the U.S. market while integrated producers resorted to 'minimillization' and rationalization programs resulting in massive industry restructuring that coincided with increased alliance activity (Madhavan and Prescott, 1995). Figure 1 for instance indicates a jump in horizontal alliances among integrated producers as occurring about 1990 as Voluntary Restraint Agreements (VRA) gave way to tariffs and quotas that engulfed even foreign producers. Alliances appeared to have provided the beleaguered foreign producers a 'safe' mode for participation in the U.S steel market. The following section highlights a few of the steel alliances to illustrate their role in the industry.

\section{The Role of Horizontal Alliances in the Industry}

Horizontal alliances matched the needs of domestic and foreign producers by enabling integrated producers to mobilize the requisite capabilities to face foreign and minimill induced competitive pressures and by providing foreign firms means of entry into the lucrative but high capacity industry. Domestic partners pursued capabilities such as thin-slab casting to distinguish them in the increasingly crowded and interdependent competitive environment. For instance, the Canadian producer Algoma Steel partnered with U.S producers on a new steel making process that combined thin-slab rolling with conventional blast furnace technology. The technology blends the blast furnace advantages of low cost and clean liquid steel with the low conversion cost and superior tolerances of thinslab-casting resulting in cost savings of $\$ 18$ to $\$ 20$ per ton over conventional methods. Examples of alliances during the study period included the 1995-97 Alabama-based Trico joint venture project between integrated steel producers LTV Corporation (U.S), British Steel, and Sumitomo (Japan); the top U.S. integrated 
steel producer U.S. Steel and the minimill paragon Nucor Steel's joint Direct Reduced Iron (DRI) project in Trinidad; the Canadian integrated Dofasco and the U.S. minimill Co-Steel's 50/50 stake in Gallatin Steel at Carrollton, Kentucky; the Japanese Nippon Steel's ten percent equity in Oregon Steel's CF\&I, and the U.S. Steel (USS) and the Korean Pohang Iron and Steel (Posco) joint venture.

\section{Old versus modern facilities}

Despite excess capacity in the industry, steel producers doubled alliance intensity from the earlier decades (Berg and Friedman, 1978) in order to establish modern production facilities since the old integrated facilities (that still counted as production capacity) were too costly to modernize for effective production. That is, alliance partners may have found it efficient to establish modern facilities while maintaining idle or underutilized (old) capacity. Not only did the alliances create more capacity but competition as well since partners competed with each other and with their joint facilities. For instance, the USS-Posco's Pittsburg plant obtained its steel from three sources: U.S. Steel's Gary (Indiana) Works, U.S. Steel's Fairfield (Alabama) Works, and Pohang Iron and Steel (Posco) in Korea. Posco shipped its hot-band coils some 6,000 miles across the Pacific Ocean into the Sacramento River/San Joaquin river delta ( 40 miles east of San Francisco Bay). The complex material sourcing arrangement required readjustments at USS-Posco (the joint venture) since the three sources of steel (Gary, Fairfield, and Posco) made bands with different yield capabilities. Steel from Fairfield yielded about 1,000 pounds per inch of width; Gary, 1,100; and Posco, 1,150. Fairfield's coils also had more crown than those from Gary or from Posco. Consequently, the Pittsburgh mill adapted processing to handle the differential capabilities making the facility one of the most complex integrated plants in the U.S. These complexities required USS-Posco management to devise "an adaptive system" that allowed for equipment movement and shifts to synchronize the multiple material sourcing from competing partners (American Metal Market, 1997 Archived).

\section{Conflict versus co-operation}

USS-Posco also confronted competition from the parents firms-- U.S. Steel and Posco: "U.S. Steel owns 50 percent, and they look at us in terms of what is best for U.S. Steel. Posco owns 50 percent, and they are looking out for what's best for Posco. At USS-Posco, we have to look out for what's best for us. [Further,] U.S. Steel competes with us by shipping tin plate" (American Metal Market, 1997 Archived). The ensuing rivalry between the parent firms and between the parents and USS-Posco impacted the joint venture's initial performance adversely. After four-years of losses however, USS-Posco finally pulled a profit in 1992 and achieved $\$ 80$ million operating income in 1993 over the 1990 period. Workforce productivity rose and integrated yield increased by 17 percent for tin products and by 12 percent for sheet. USS-Posco management attributed much of the increased yield to the high quality and uniformity of the hot band steel that Posco shipped that aided gauge control at its California mill. USS-Posco 
(the joint venture) therefore aided Posco's entry into the U.S steel market and enabled U.S. Steel to raise productivity.

\section{Technological breakthroughs}

Since the early 1980's when Nucor spearheaded the revolutionary Compact Strip Production (CSP) technology, the U.S. steel industry observers considered the industry ripe for technological breakthrough and touted the DRI technology as CSP's successor (AISI, 1997). The technology was superior to the blast furnace method of iron making. For instance, an experimental direct-process plant in Pittsburgh that had been in operation since the late eighties yielded five tons of steel an hour and shaved about $20 \%$ off conventional steel making. The facility used a coal-based, continuous in-bath melting process that substituted a single vessel for coke ovens, blast furnaces, and basic oxygen furnaces. Widespread implementation of DRI process was expected to reduce costs by eliminating old coke ovens that polluted the environment and that were expensive to rebuild. However, the DRI technology was expensive for a single firm to develop. Consequently, the Nucor-U.S. Steel joint effort teamed the top producers' complementary resources in spearheading the development of the most likely revolutionary solution to problems caused by the capital-intensive nature of the integrated steelmaking process. Through the alliance, Nucor obtained access to financial capital for R\&D into DRI technology while U.S. Steel gained access to Nucor's pragmatic technological agility.

This study documents potential impacts of capability horizontal alliances on industry profitability and competitiveness and is particularly timely for U.S. steel firms that confront mounting competitive pressures with ineffectual political strategies such as tariffs (Schuler, 1996). Although popular among steel firms, these strategies are limited in addressing competitive pressures from foreign firms with direct domestic investment and the minimill-induced competitive pressures (Moore, 1994). Rather, this study suggests that capability horizontal alliances may offer a better strategic alternative for the industry. The study offers a capability hypothesis that does not preclude simultaneous competitive and co-operative alliance motivations, but is contrary to conventional wisdom that eschews horizontal alliances as market power driven and therefore anti-competitive. Stakeholders may take comfort in the sufficiency of competitive element in horizontal alliances to safeguard against 'over-cooperation.'

\section{References}

Acs, Z. J. (1984). The changing structure of the U. S. economy: Lessons from the steel industry. New York: Praeger Publishers.

Aiken, L.S. \& West, S.G. (1991). Multiple regression testing and interpreting interactions. Newbury: Park Sage. 
American Iron \& Steel Institute (AISI). (1997). Steel Survival Strategies XII Meeting. New York: SteelNet.com, accessed August 1997.

Barnett, D.F. \& Crandall, R.W. (1986). Up from the ashes: The rise of the steel minimill in the United States. Washington, D.C: The Brookings Institution.

Barney, J.B. (1991). Firm resources and sustained competitive advantage. Journal of Management, 17, 99-120.

Berg, S. \& Friedman, P. (1977). Joint ventures, competition, and technological complementarities: Evidence from chemicals. Southern Economic Journal, 1330-1337.

Berg, S. \& Friedman, P. (1978). Joint ventures in American industry. Mergers \& Acquisitions, Summer, 28-41.

Berg, S. \& Friedman, P. (1981). Impacts of domestic joint ventures on industrial rates of return: $A$ pooled cross-section analysis. The Review of Economics and Statistics, 293-298.

Bhaskar, V., Manning, A., \& To, T. (2002). Oligopsony and monopsonistic competition in labor markets. Journal of Economic Perspectives 16(2), 155-174.

Burgers, W.P., Hill, C.W., \& Kim, W.C. (1993). A theory of global strategic alliances: The case of the global auto industry. Strategic Management Journal, 14(6), 419-432.

Chan, S.H., Kensinger, J.W., Keown, A.J., \& Martin, J.D. (1997). Do strategic alliances create value? Journal of Financial Economics 46(2), 199-221.

Chandler, A.D. (1990). Scale and scope: The dynamics of industrial capitalism. Cambridge: Harvard University Press.

Chi, T. (1994). Trading in strategic resources: Necessary conditions, transaction cost problems, and choice of exchange structure. Strategic Management Journal, 15(4), $271-290$.

Das, S., Sen, P.K., \& Sengupta, S. (1998). Impact of strategic alliances on firm valuation. Academy of Management Journal, 41(1), 27-41.

Dyer, J.H. (1997). Effective inter-firm collaboration: How firms minimize transaction costs and maximize transaction value. Strategic Management Journal, 18(7), 535-556.

Fusfeld, D.R. (1958). Joint subsidiaries in the iron and steel industry. American Economic Review, 48, 578-587.

Godfrey, P.C. \& Hill, C.W. (1995). The problem of unobservables in strategic management research. Strategic Management Journal, 16, 519-533. 
Goes, B.J. \& Park, H.S. (1997). Inter-organizational links and innovation: The case of hospital services. Academy of Management Journal, 40(3), 673-696.

Goolsbee, A. \& Chevalier, J. (2002). Measuring prices and price competition online: Amazon and Barnes and Noble. Working Paper \# 9085, National Bureau of Economic Research.

Grant, R.M. (1991). Contemporary strategy analysis. Cambridge: Blackwell Publishers.

Hamel, G. (1991). Competition for competence and inter-partner learning within international strategic alliances. Strategic Management Journal, Summer Special Issue, 83-103.

Hogan, W.T. (1994). Steel in the 21 st Century: Competition forges a new world order. New York: Lexington Books.

Hurry, D. (1993). Restructuring in the global economy: The consequences of strategic linkages between Japanese and U. S. firms. Strategic Management Journal, 14, 69-82.

Jennings, D.F., Artz, K., Gillin, L.M., \& Christodouloy, C. (2000). Determinants of trust in global strategic alliances: AMRAD and the Australian biomedical industry. Competitiveness Review, 10(1).

Kennedy, P. (1992). A guide to econometrics. Boston: The MIT Press.

Kogut, B. (1988). Joint ventures: Theoretical and empirical perspectives. Strategic Management Journal, 9(4), 319-332.

Kogut, B. (1991). Joint ventures and the option to expand and acquire. Management Science, $37(1), 19-33$.

Kotabe, M. \& Swan, K.S. (1995). The role of strategic alliances in high-technology new product development. Strategic Management Journal, 16(8), 621-636.

Lado, A.A., Boyd, N.G., \& Hanlon, S.C. (1997). Competition, cooperation and the search for economic rents: A syncretic model. Academy of Management Review, 22(1), 110 141.

Leonard-Barton, D. (1995). Wellspring of knowledge: Building and sustaining the sources of innovation. Cambridge: Harvard University Press.

Lieberman, M. B. \& Johnson, D. R. (1995). Comparative productivity of Japanese and US steel producers, 1958-1993. Working Paper S\&O 95-7 \# 034. University of California at Los Angeles.

Madhavan, R. \& Prescott, J.E. (1995). Market value impact of joint ventures: The effect of industry information-processing load. Academy of Management Journal, 38(3), 900-915. 
Mahoney, J.T. \& Pandian, J.R. (1992). The resource-based view within the conversation of strategic management. Strategic Management Journal, 13, 559-584.

Mariotti, J.L. (1996). The power of partnerships. Boston: Blackwell Publishers.

Moore, M.O. (1994). "Steel protection in the 1980s: The waning influence of big steel? Working Paper \# 4760, National Bureau of Economic Research.

Mueller, C. \& Herstatt, C. (2000). Interfirm cooperation: A brief overview of current theoretical findings and issues for future research. International Journal of Human Resources Development and Management, 1(1), 48-67.

Nelson, R.R. \& Winter, S.G. (1982). An evolutionary theory of economic change. Cambridge: Harvard University Press.

Neter, J., Wasserman, W. \& Kutner, M.H. (1990). Applied linear statistical models. Howewood: Richard D. Irwin Inc.

Ojode, L.A. (2000). A resource-based view of strategic alliances: Organizational capabilities, governance, and performance (Doctoral dissertation. University of Illinois at Urbana-Champaign, 2000).

Parkhe, A. (1991). Interfirm diversity, organizational learning and longevity in global strategic. Journal of International Business Studies, 22(4), 579-601.

Penrose, E.T. (1959). The theory of the growth of the firm. London: Wiley.

Porter, M.E. (1980). Competitive strategy. New York: Free Press.

Schelling, T.C. (1980). The strategy of conflict. Cambridge: Harvard University Press.

Scherer, F.M. (1980). Industrial market structure and economic performance. Chicago: Rand McNally.

Scheuerman, W. (1986). The steel crisis: The economics and politics of a declining industry. New York: Praeger Publishers.

Schoemaker, P.J. (1993). Strategic decisions in organizations: Rational and behavioral views. Journal of Management Studies, 30, 107-129.

Schuler, D.A. (1996). Corporate political strategy and foreign competition: The case of the steel industry. Academy of Management Journal, 39(3), 720-737.

Stubbles, J.R. (1995). The new North American steel industry. Iron and SteelMakers, Dec., 19-27.

Stuckey, A. (1983). Vertical integration and joint ventures in the aluminum industry. Cambridge: Harvard University Press. 
Teece, D.J. \& Pisano, G. (1994). The dynamic capabilities of firms: An introduction. Industrial and Corporate Change, 3, 537-556.

Teece, D.J., Pisano, G., \& Shuen, A. (1990). Firm capabilities, resources and the concept of strategy. Working Paper \# 90-9, University of California at Berkeley.

Wernerfelt, B.A. (1984). A resource-based view of the firm. Strategic Management Journal, 5, 171-181.

Williamson, O.E. (1968). Economies as an antitrust defense: The welfare tradeoffs. American Economic Review, 58, 18-36.

\section{Footnotes}

${ }^{1}$ Ojode (2000) provides sample description of steel alliances, partner stated objectives, and related data.

${ }^{2}$ I am thankful to the anonymous $J B S$ reviewer who raised the issue of horizontal alliances and excess worldwide steel production capacity.

${ }^{3}$ By the end of the VRA in early 1990 s, U.S steel firms filed more than eighty suits against foreign steelmakers for dumping leading to new tariffs across the board that covered even foreign firms with direct investment in the U.S. By 2003 the steel industry was still struggling with 8-30 percent tariffs.

Dr. Ojode obtained her doctorate in business administration (Strategic Management and International Business) from the University of Illinois in 2000. An Assistant Professor of Management at Texas Southern University, she teaches business policy/strategy to undergraduate and MBA students. She has also taught business policy/strategy and international business at Indiana University and at the United States International University in Nairobi, Kenya. Her research interests revolve around resource-based perspectives; transaction costs economics; strategic alliances and international business strategies. 